\title{
Mathematical modeling of thin layer drying kinetics of apples slices
}

\author{
Nasser Hamdami ${ }^{\text {a,b, }}$, Mehrzad Sayyad ${ }^{\mathrm{b}}$ and Ali Oladegaragoze ${ }^{\mathrm{c}}$ \\ ${ }^{a}$ Department of Food Science and Technology, College of Agriculture, Isfahan University of \\ Technology, Isfahan 84156, Iran \\ ${ }^{b}$ Department of Food Science and Technology, University of Tabriz, Tabriz 51664, Iran \\ ${ }^{c}$ Department of Applied Chemistry, University of Tabriz, Tabriz 51664, Iran
}

\begin{abstract}
This study presents a mathematical modeling of thin layer drying of apple slices in a forced convection dryer. In order to estimate and select the appropriate drying model, ten different models which are semi-theoretical and/or empirical were applied to the experimental data and compared.

In this research, the rectangular $(20 \times 20 \times 5 \mathrm{~mm})$ apple slices sample were dried as single layer with thickness of $5 \mathrm{~mm}$ in the air temperature range of $45-60{ }^{\circ} \mathrm{C}$ and the air velocity of 0.75 $1.25 \mathrm{~m} / \mathrm{s}$ in a hot air dryer. Then, the mathematical models were fitted to the experimental data. The models were compared with using the correlation coefficient and the root mean square error. According to the results, the Wang and Sing model was found to best explain thin layer drying behavior of the apple slices as compared to the other models over the experimental temperature and air velocity range.

The effects of drying air temperature and velocity just above their surface on the constants and coefficients of the selected models were also studied by linear regression analysis.

Keywords: Apple; Drying kinetic; Thin layer modeling
\end{abstract}

\section{Introduction}

Drying is one of the widely used methods of fruit and vegetable preservation. The basic objective in drying agricultural products is the removal of water in the solid up to certain level, at which microbial spoilage and deterioration chemical reaction are greatly minimized (Krokida and Marinos-Kouris 2003). In most drying processes water is removed by convective evaporation in which heat is supplied by hot air. Dehydrated products can be used in many processed or ready-to-eat food in place of fresh food and have several advantage such as convenience in transportation, storage, preparation and use. Apple is an important raw material for many food products. The apples are consumed either fresh consumption or in the form of various processed products such as juice, jam, marmalade and dried product. Several studies have been carried out to investigate the drying characteristics of the apple (Funebo and Ohlsson 1998; Nieto, Salvatori et al. 1998; wang and Chao 2002; Anders, Bilbao et al. 2004; Velic, Planinic et al. 2004). Drying influence physicochemical and quality characteristic of products, thus, modeling of drying kinetic is one tool for process control. Evaluation of drying kinetic as a function of drying conditions could help us in drying simulation for predicting the suitable drying conditions. Many mathematical models have been used to describe the drying process of food products. The most widely used theoritical drying model has been Fick's second law. Drying of many food products such as rice (Ece and Cihan 1993) and hazelnut (Demirtas, ayhan et al. 1998) has been successfully predicted using Fick's second law. Semitheoretical models often offer an ease of use which is valid within the temperature, relative humidity, air velocity and moisture content range for which they were developed (Fortes and Okos 1981). There have been many studies on thin layer drying of grains (Cao, Nishiyama et

\footnotetext{
${ }^{*}$ Corresponding author. Tel.: +98-311-391-34-28 Fax: +98-311-391-22-54.

E-mail addresses: hamdami@cc.iut.ac.ir
} 
al. 2004; Gaston, Abalone et al. 2004), fruits (Doymaz 2004; Velic, Planinic et al. 2004; Doymaz 2004c; Velic, Planinic et al. 2004c; Simal, Femenia et al. 2005), vegetables (Doymaz 2004b) leaves and grasses (Demir, Gunhan et al. 2004). Thin layer drying, mean to dry as one layer of sample particles or slices. Many mathematical models have described the thin-layer drying process of food products. Among the thin layer drying models, the Henderson and Pabis model, the Two-term model, the Lewis model, the Page's model, the Thomson model and the Wang and Singh model are used frequently in literature.

The present study was therefore undertaken to investigate the thin layer drying characteristic of organic apple in a convective dryer and to fit the experimental data to represented mathematical models in Table 1.

Table1: Analytical models

\begin{tabular}{|c|l|l|}
\hline Number & Models & Equations \\
\hline 1 & Lewis model & $M R=\exp (-k t)$ \\
\hline 2 & Henderson and Pabis & $M R=a \times \exp (-k t)$ \\
\hline 3 & Logarithmic & $M R=a \times \exp (-k t)+c$ \\
\hline 4 & Page's model & $M R=\exp \left(-k t^{n}\right)$ \\
\hline 5 & Modified page & $M R=\exp \left[-(k t)^{n}\right]$ \\
\hline 6 & Two-term model & $M R=a \times \exp \left(-k_{1} t\right)+b \times \exp \left(k_{2} t\right)$ \\
\hline 7 & Wang and Singh model & $M R=1+a \times t+b \times(\ln M R)^{2}$ \\
\hline 8 & Approximation of diffusion & $M R=a \times \exp (-k t)+(1-a) \times \exp (-k b t)$ \\
\hline 9 & Modified Henderson and Pabis & $M R=a \times \exp (-k t)+b \times \exp (-g t)+c \times \exp (-h t)$ \\
\hline 10 & Midilli and Kucuk & $M R=a \times \exp \left(-k t^{n}\right)+b t$ \\
\hline
\end{tabular}

\section{Material and methods}

\subsection{Drying system}

A convective dryer was used in this investigation (Fig.1). The experimental dryer consist of a centrifugal blower, an electrical resistance air heating section, the measurement sensors and the data recording system coupled with a personal computer. The air velocity was continuously measured using an anemometer. The weight of the dried sample was measured using a digital balance with an accuracy of $0.1 \mathrm{~g}$ having a maximum capacity of $2000 \mathrm{~g}$. The measurement data were collected using a data logger interfaced to the personal computer and then recorded in fixed time intervals $(1.6 \mathrm{~s})$. A door was provided in front of side of the chamber for placing and removing the sample tray. The blower and heater of dryer were switched on for 20 minute for the drying air to reach a stable temperature.

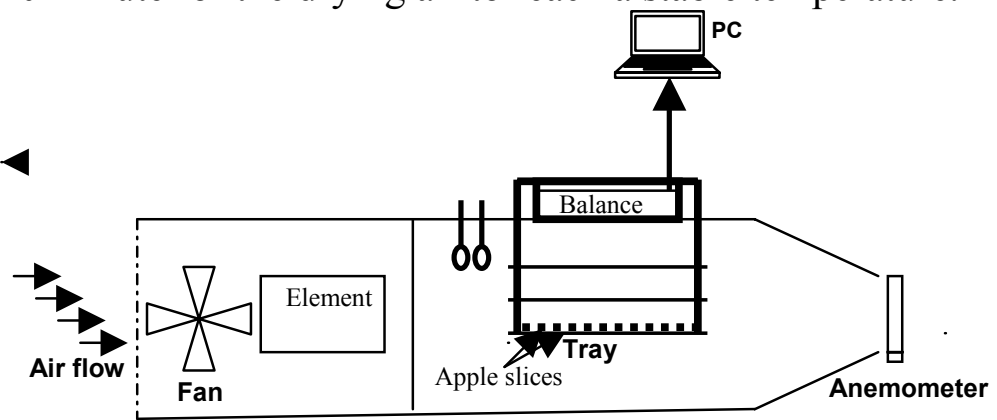

Fig.1.schematic diagram of the convective dryer used in this study 


\subsection{Sample preparation and drying conditions}

In this research, thin layer drying experiments were conducted for Golden apples grown in East Azarbaijan, Iran. Initial moisture content of apple samples was between $84 \%$ and $88 \%$ (wet base). No pre-treatment was applied to the fresh product. Apples were obtained from a local supplier and stored at $4{ }^{\circ} \mathrm{C}$. After $1 \mathrm{hr}$ stabilization at the ambient temperature apple were hand peeled and cut to the rectangle-shaped slices $(20 \times 20 \times 5 \mathrm{~mm})$ with thickness of $5 \mathrm{~mm}$. Samples were placed on the tray in a single layer in dryer where only one face of slices was in contact with the drying air and the other face was in contact with the support. The experiments were carried out at air velocities $0.75,1$ and $1.25 \mathrm{~m} / \mathrm{s}$ and temperature $45,50,55$ and $60^{\circ} \mathrm{C}$ until a mean moisture content of about $40 \%$ (wet base). The experiment was conducted in triplicate. Temperature and relative humidity of the drying air were recorded during the drying process.

2.3. Drying curve

The moisture content data obtained at different drying air temperature were converted to the moisture ratio $(M R)$.

$$
M R=\frac{X-X_{e}}{X_{0}-X_{e}}
$$

The moisture content of samples $(X)$ was estimated by drying 5 gr of sample in an oven at $105^{\circ} \mathrm{C}$ and the equilibrium moisture content $\left(X_{e}\right)$ of samples at different relative humidifies and temperature levels of drying air was calculated using the Guggenheim-Anderson-de Boer (G.A.B.) model. The GAB equation is :

$$
\frac{X_{e}}{X_{m}}=\frac{C \cdot K \cdot a_{w}}{\left(1-K . a_{w}\right)\left(1-K . a_{w}+C \cdot K \cdot a_{w}\right)}
$$

where the three parameters $a_{w}, X_{e}$ and $X_{m}$ are respectively, water activity, mean water content of sample $\left(\mathrm{g} \mathrm{H}_{2} \mathrm{O} / 100 \mathrm{~g}\right.$ dry matter) and water content of the GAB model monolayer ( $\mathrm{g}$ $\mathrm{H}_{2} \mathrm{O} / 100 \mathrm{~g}$ dry matter) that is equal to 0.18 for apple. $C$ and $K$ are the constants of the GAB model that their relation with temperature $(\mathrm{K})$ can be presented by these equations:

$$
\begin{gathered}
C=C_{o} \cdot \exp \left(\frac{\Delta H_{c}}{R T}\right) \\
K=K_{o} \cdot \exp \left(\frac{\Delta H_{K}}{R T}\right)
\end{gathered}
$$

where the values of $C_{o}, K_{o}, \Delta H_{c}$ and $\Delta H_{k}$ are respectively equal to $0.79,0.085,84.93$ and 751.88 (Maroulis, Kiranoudis et al. 1995).

The drying curve for each experiment was obtained by plotting the dimensionless moisture of the sample vs. the drying time

2.4. Mathematical modeling of drying curves

In order to estimate and select the appropriate drying model between ten different models (semi-theoretical and/or empirical models), firstly, the Levenberg-Marquardt method of nonlinear optimization was used to determine the parameters of the thin layer drying models by fitting experimental data to the model equation. Then, the models were compared with using the correlation coefficient $(r)$ and the root mean square error (RMSE). The drying model with higher $r$ and lower RMSE was selected as the best model describing the thin layer drying characteristics of apple. Finally, the relationship of the identified parameters of the best model with the drying variables such as drying air temperature and velocity was determined. 


\section{Result and discussion}

\subsection{Drying curves}

Figure 2 shows a typical drying curve for the sliced apple samples at $50^{\circ} \mathrm{C}$ and $0.75 \mathrm{~m} / \mathrm{s}$. Although not shown, the drying curves at the other conditions studied were similar. The drying data obtained in the experiments were converted to dimensionless amount of moisture ratio $(M R)$. Figs 3 and 4 present the evolution of the moisture ratio as a function of the drying time at the different temperatures for a constant air velocity and at the different air velocities for a constant air temperature, respectively. It can be observed that moisture ratio decreased exponentially with time. Difference between moisture ratios increased gradually as from starting of drying. With increasing the temperature and air velocity, the time required to arrive certain moisture content is decreased. Consequently, the effect of air temperature and velocity has been reflected in drying rate. Similar results were reported by Ozdemir and Derves (1999).

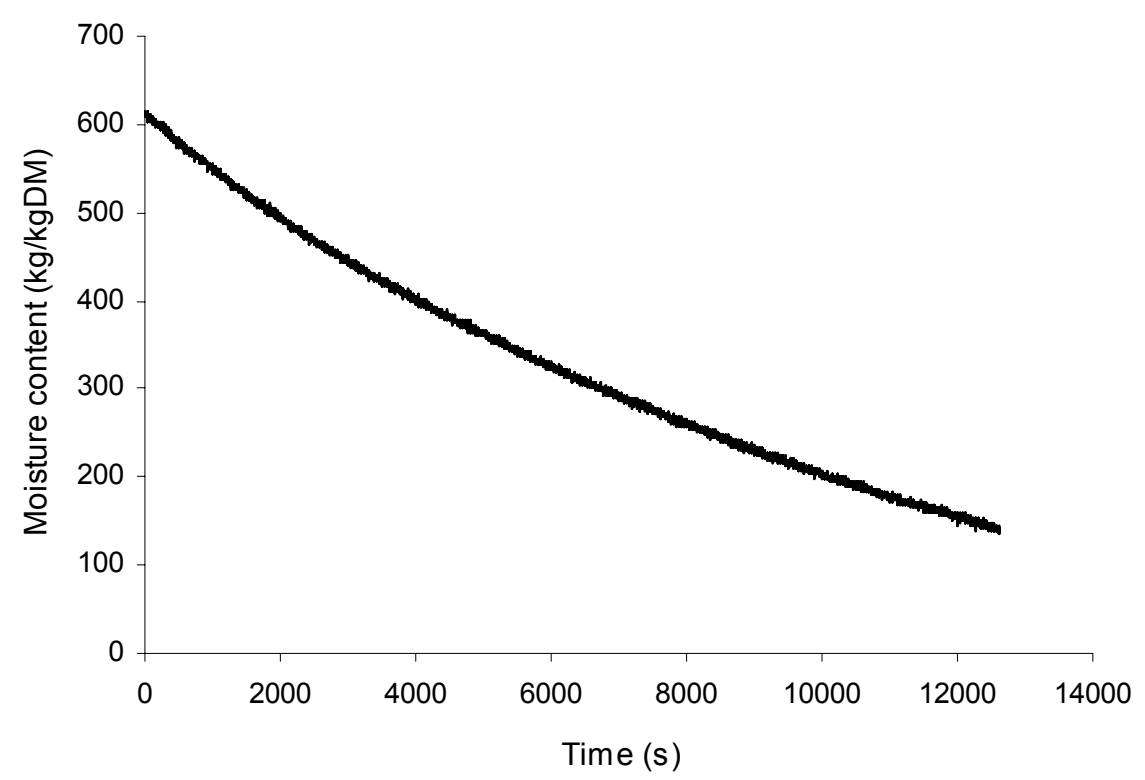

Figure 2. Typical drying curves of the slices apple at $50^{\circ} \mathrm{C}$ and $1 \mathrm{~m} / \mathrm{s}$.

\subsection{Modeling of drying curves}

In order to determine the moisture ratio as a function of drying time at the different temperatures and air velocities, ten drying model were fitted with experimental data and their correlation coefficients and RMSE were calculated. 


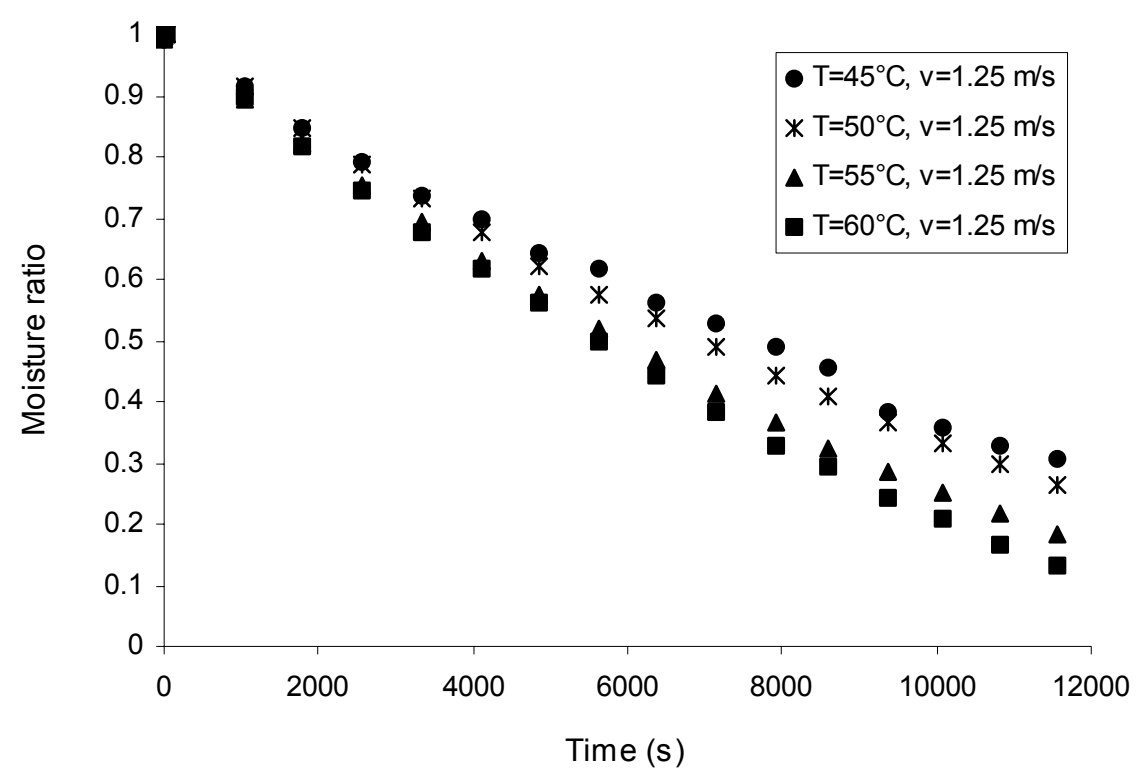

Figure 3. Evolution of experimental moisture ratio values during drying of apple slices at the different temperature

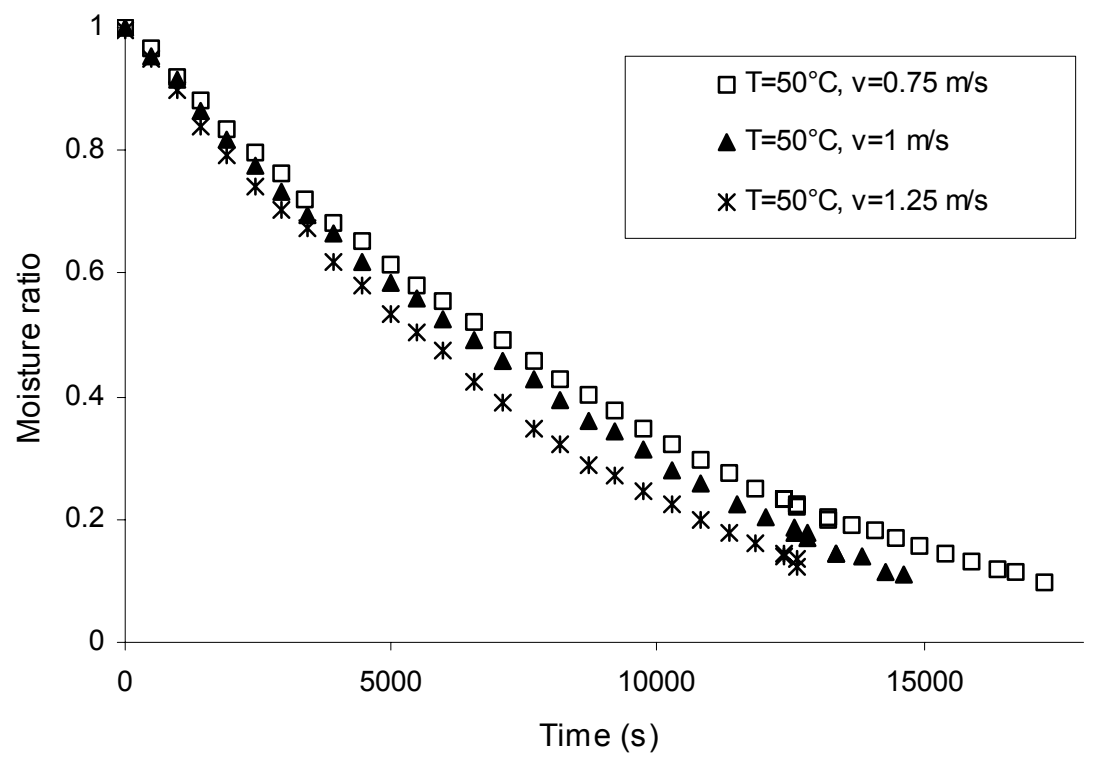

Figure 4. Evolution of experimental moisture ratio values during drying of apple slices at the different air velocity

The average value of correlation coefficients and RMSE values of 10 models used in this study are given in Tables 2 and 3, respectively. The values of $r$ and RMSE for these models vary between 0.0891 and 1 , and $1.6 \times 10^{-6}$ and $1.55 \times 10^{-3}$, respectively. It is assumed that the model which has the highest $r$ and lowest RMSE is the best-suited one. Therefore, the models 3, 7 and 8 (Logarithmic, Wang and Sing and Approximation of diffusion models, respectively) were better than the other models. But, among these three models, the Wang and Sing model has the minimum number of the model constants. Hence, Wang and Sing model was selected in the present study to predict and represent the thin layer drying behavior of apple slices. 
Table2. Correlation coefficients $(r)$ obtained from various thin layer models

\begin{tabular}{|c|c|c|c|c|c|c|c|c|c|c|c|}
\hline \multicolumn{10}{|c|}{ Drying air condition } & \multicolumn{7}{|c|}{ Model number according to the Table 1 } \\
\hline $\mathrm{T}\left({ }^{\circ} \mathrm{C}\right)$ & $v(\mathrm{~m} / \mathrm{s})$ & 1 & 2 & 3 & 4 & 5 & 6 & 7 & 8 & 9 & 10 \\
& & & & & & & & & & & \\
\hline 45 & 1.25 & 0.997 & 0.996 & 1.000 & 1.000 & 0.997 & 0.996 & 1.000 & 1.000 & 0.999 & 0.999 \\
45 & 1 & 0.997 & 0.997 & 1.000 & 0.998 & 0.9972 & 0.997 & 1.000 & 1.000 & 0.998 & 0.999 \\
45 & 0.75 & 0.997 & 0.996 & 1.000 & 1.000 & 0.9953 & 0.996 & 1.000 & 1.000 & 0.999 & 1.000 \\
50 & 1.25 & 0.998 & 0.997 & 1.000 & 1.000 & 0.998 & 0.997 & 1.000 & 1.000 & 0.999 & 0.999 \\
50 & 1 & 0.997 & 0.996 & 1.000 & 1.000 & 0.9968 & 0.996 & 1.000 & 1.000 & 0.999 & 1.000 \\
50 & 0.75 & 0.998 & 0.997 & 1.000 & 1.000 & 0.9974 & 0.997 & 1.000 & 1.000 & 0.999 & 1.000 \\
55 & 1.25 & 0.997 & 0.996 & 1.000 & 1.000 & 0.9963 & 0.996 & 1.000 & 1.000 & 0.999 & 1.000 \\
55 & 1 & 0.998 & 0.998 & 1.000 & 1.000 & 0.9975 & 0.998 & 1.000 & 1.000 & 1.000 & 1.000 \\
55 & 0.75 & 0.996 & 0.995 & 1.000 & 1.000 & 0.9955 & 0.995 & 1.000 & 1.000 & 0.998 & 0.999 \\
60 & 1.25 & 0.996 & 0.994 & 1.000 & 1.000 & 0.9965 & 0.994 & 1.000 & 1.000 & 0.999 & 1.000 \\
60 & 1 & 0.891 & 0.996 & 1.000 & 0.999 & 0.996 & 0.996 & 1.000 & 1.000 & 0.999 & 1.000 \\
60 & 0.75 & 0.995 & 0.993 & 1.000 & 1.000 & 0.9957 & 0.993 & 1.000 & 1.000 & 0.999 & 1.000 \\
\hline
\end{tabular}

Table3. Root mean square error obtained from various thin layer models

\begin{tabular}{|c|c|c|c|c|c|c|c|c|c|c|c|}
\hline \multicolumn{2}{|c|}{ Drying air condition } & \multicolumn{10}{|c|}{ Model number according to the Table 1} \\
\hline $\begin{array}{c}\text { Temperature } \\
\left({ }^{\circ} \mathrm{C}\right)\end{array}$ & $\begin{array}{c}\text { Velocity } \\
(\mathrm{m} / \mathrm{s})\end{array}$ & 1 & 2 & 3 & 4 & 5 & 6 & 7 & 8 & 9 & 10 \\
\hline & & 6.07E- & $4.68 \mathrm{E}-$ & 4.86E- & 1.94E- & $6.19 \mathrm{E}-$ & $4.68 \mathrm{E}-$ & $1.01 \mathrm{E}-$ & $5.32 \mathrm{E}-$ & $1.19 \mathrm{E}-$ & 6.07E- \\
\hline 45 & 1.2 & $\begin{array}{c}04 \\
6.19 \mathrm{E}-\end{array}$ & $\begin{array}{c}04 \\
4.65 \mathrm{E}-\end{array}$ & $\begin{array}{c}05 \\
4.35 \mathrm{E}-\end{array}$ & $\begin{array}{c}04 \\
2.21 \mathrm{E}-\end{array}$ & $\begin{array}{c}04 \\
6.20 \mathrm{E}-\end{array}$ & $\begin{array}{c}04 \\
4.65 \mathrm{E}-\end{array}$ & $\begin{array}{c}04 \\
1.16 \mathrm{E}\end{array}$ & $\begin{array}{c}05 \\
4.75 \mathrm{E}-\end{array}$ & $\begin{array}{c}04 \\
2.33 \mathrm{E}-\end{array}$ & 04 \\
\hline 45 & 1 & $\begin{array}{r}0.195 \\
04\end{array}$ & $\begin{array}{l}4.05 \mathrm{E}^{-} \\
04\end{array}$ & $\begin{array}{l}4.305- \\
05\end{array}$ & 04 & $\begin{array}{ll}0.20 \mathrm{~L}- \\
04\end{array}$ & $\begin{array}{l}4.005- \\
04\end{array}$ & $\begin{array}{c}1.10 \mathrm{E}- \\
04\end{array}$ & 05 & 04 & 04 \\
\hline 45 & 0.75 & $\begin{array}{c}8.98 \mathrm{E}- \\
04\end{array}$ & $\begin{array}{c}5.57 \mathrm{E}- \\
04\end{array}$ & $\begin{array}{l}2.40 \mathrm{E}- \\
05\end{array}$ & $\begin{array}{c}1.20 \mathrm{E}- \\
04\end{array}$ & $\begin{array}{c}1.90 \mathrm{E}- \\
03\end{array}$ & $\begin{array}{l}5.57 \mathrm{E}- \\
04\end{array}$ & $\begin{array}{c}2.22 \mathrm{E}- \\
05\end{array}$ & $\begin{array}{l}3.77 \mathrm{E}- \\
05\end{array}$ & $\begin{array}{c}8.45 \mathrm{E}- \\
05\end{array}$ & $\begin{array}{c}8.98 \mathrm{E}- \\
04\end{array}$ \\
\hline 50 & & $5.11 \mathrm{E}-$ & 3.51E- & 5.01E- & $1.45 \mathrm{E}-$ & 5.44E- & 3.51E- & $1.12 \mathrm{E}-$ & $5.49 \mathrm{E}-$ & $1.06 \mathrm{E}-$ & 5.11E- \\
\hline 30 & & $\begin{array}{l}04 \\
6.82 \mathrm{E}-\end{array}$ & $\begin{array}{c}04 \\
5.03 \mathrm{E}-\end{array}$ & $\begin{array}{c}05 \\
2.36 \mathrm{E}-\end{array}$ & $\begin{array}{c}04 \\
2.01 \mathrm{E}-\end{array}$ & $\begin{array}{c}04 \\
7.11 \mathrm{E}-\end{array}$ & $\begin{array}{c}04 \\
5.03 E-\end{array}$ & $\begin{array}{c}04 \\
9.20 \mathrm{E}-\end{array}$ & \begin{tabular}{|c}
05 \\
$2.73 \mathrm{E}$
\end{tabular} & $\begin{array}{c}04 \\
1.39 \mathrm{E}-\end{array}$ & $\begin{array}{l}04 \\
82 \mathrm{E}-\end{array}$ \\
\hline 50 & 1 & 04 & $\begin{array}{l}04 \\
0\end{array}$ & 05 & 04 & 04 & 04 & 05 & 05 & 04 & 04 \\
\hline 50 & 0.75 & $\begin{array}{c}7.80 \mathrm{E}- \\
04\end{array}$ & $\begin{array}{c}4.92 \mathrm{E}- \\
04\end{array}$ & $\begin{array}{c}1.70 \mathrm{E}- \\
05\end{array}$ & 1.31E- & 7.89E- & $\begin{array}{l}4.92 \mathrm{E}- \\
04\end{array}$ & $\begin{array}{c}2.88 \mathrm{E}- \\
05\end{array}$ & $\begin{array}{c}2.52 \mathrm{E}- \\
05\end{array}$ & $\begin{array}{c}9.20 \mathrm{E}- \\
05\end{array}$ & $\begin{array}{l}7.80 \mathrm{E}- \\
04\end{array}$ \\
\hline & & $6.93 \mathrm{E}-$ & 4.97E- & $2.96 \mathrm{E}-$ & $1.91 \mathrm{E}-$ & $1.01 \mathrm{E}-$ & $4.97 \mathrm{E}-$ & 7.33E- & $2.99 \mathrm{E}-$ & $1.34 \mathrm{E}-$ & 6.93E- \\
\hline 55 & 1.25 & 04 & 04 & 05 & 04 & 03 & 04 & 05 & 05 & 0 & 01 \\
\hline 55 & 1 & $\begin{array}{c}6.03 \mathrm{E}- \\
04\end{array}$ & $\begin{array}{c}3.38 \mathrm{E}- \\
04\end{array}$ & $\begin{array}{c}2.15 \mathrm{E}- \\
05\end{array}$ & $\begin{array}{c}7.16 \mathrm{E}- \\
05\end{array}$ & $\begin{array}{c}1.58 \mathrm{E}- \\
03\end{array}$ & $\begin{array}{c}3.38 \mathrm{E}- \\
04\end{array}$ & $\begin{array}{c}3.79 \mathrm{E}- \\
05\end{array}$ & $\begin{array}{c}3.86 \mathrm{E}- \\
05\end{array}$ & $\begin{array}{c}5.75 \mathrm{E}- \\
05\end{array}$ & $\begin{array}{c}6.03 \mathrm{E}- \\
04\end{array}$ \\
\hline & & $1.06 \mathrm{E}-$ & 7.37E- & $6.64 \mathrm{E}-$ & $2.57 \mathrm{E}-$ & $1.23 \mathrm{E}-$ & 7.37E- & 7.78E- & $6.79 \mathrm{E}-$ & 2.00E- & 1.06E- \\
\hline 55 & 0.75 & 03 & 04 & 05 & 04 & $0 ?$ & 04 & $0 t$ & 05 & 0 & 03 \\
\hline 60 & 1.25 & $\begin{array}{c}1.48 \mathrm{E}- \\
03\end{array}$ & 9.93E- & $\begin{array}{l}6.01 \mathrm{E}- \\
05\end{array}$ & $\begin{array}{c}2.46 \mathrm{E}- \\
04\end{array}$ & $\begin{array}{c}1.52 \mathrm{E}- \\
03\end{array}$ & 9.93E- & 3.31E- & 8.14E- & 2.02E- & 1.48E- \\
\hline & & $9.63 \mathrm{E}-$ & $5.70 \mathrm{E}-$ & 3.00E- & $1.95 \mathrm{E}-$ & $1.07 \mathrm{E}-$ & $5.70 \mathrm{E}-$ & $4.83 \mathrm{E}-$ & $3.15 \mathrm{E}-$ & $1.33 \mathrm{E}-$ & $9.63 \mathrm{E}-$ \\
\hline 60 & 1 & 04 & 0 & 05 & 04 & $0 ?$ & & 0 & 0 & 0 & 04 \\
\hline & & $1.55 \mathrm{E}-$ & 1.33E- & 1.69E- & $2.08 \mathrm{E}-$ & 1.53E- & $9.53 \mathrm{E}-$ & $1.57 \mathrm{E}$ & 3.05E- & $1.82 \mathrm{E}-$ & 1.55E- \\
\hline & & & & & & & & & 0 & 04 & 03 \\
\hline
\end{tabular}

Table 4. Identified constant parameters of the Wang and Sing model

\begin{tabular}{llll}
\hline$v(\mathrm{~m} / \mathrm{s})$ & $\mathrm{T}\left({ }^{\circ} \mathrm{C}\right)$ & $\mathrm{a}$ & $\mathrm{b}$ \\
\hline 1.25 & 45 & $-8.31 \mathrm{E}-05$ & $1.90 \mathrm{E}-09$ \\
& 50 & $-1.06 \mathrm{E}-04$ & $3.17 \mathrm{E}-09$ \\
& 55 & $-1.23 \mathrm{E}-04$ & $4.11 \mathrm{E}-09$ \\
& 60 & $-1.53 \mathrm{E}-04$ & $6.05 \mathrm{E}-09$ \\
\hline 1 & 45 & $-7.89 \mathrm{E}-05$ & $1.71 \mathrm{E}-09$ \\
& 50 & $-9.25 \mathrm{E}-05$ & $2.22 \mathrm{E}-09$ \\
& 55 & $-1.07 \mathrm{E}-04$ & $2.97 \mathrm{E}-09$ \\
& 60 & $-1.31 \mathrm{E}-04$ & $4.56 \mathrm{E}-09$
\end{tabular}




\begin{tabular}{llll}
\hline 0.75 & 45 & $-7.20 \mathrm{E}-05$ & $1.39 \mathrm{E}-09$ \\
& 50 & $-8.76 \mathrm{E}-05$ & $2.07 \mathrm{E}-09$ \\
& 55 & $-9.73 \mathrm{E}-05$ & $2.46 \mathrm{E}-09$ \\
& 60 & $-1.05 \mathrm{E}-04$ & $2.61 \mathrm{E}-09$ \\
\hline
\end{tabular}

The estimated parameters for the Wang and Sing model are presented in Table 4. The coefficients were taken as the average value of the three drying constants. Table 4 shows a linear relation between the parameters of this model ( $a$ and $b$ ) and drying air temperature:

$$
\begin{aligned}
& a=a_{1} T+a_{2} \\
& b=b_{1} T+b_{2}
\end{aligned}
$$

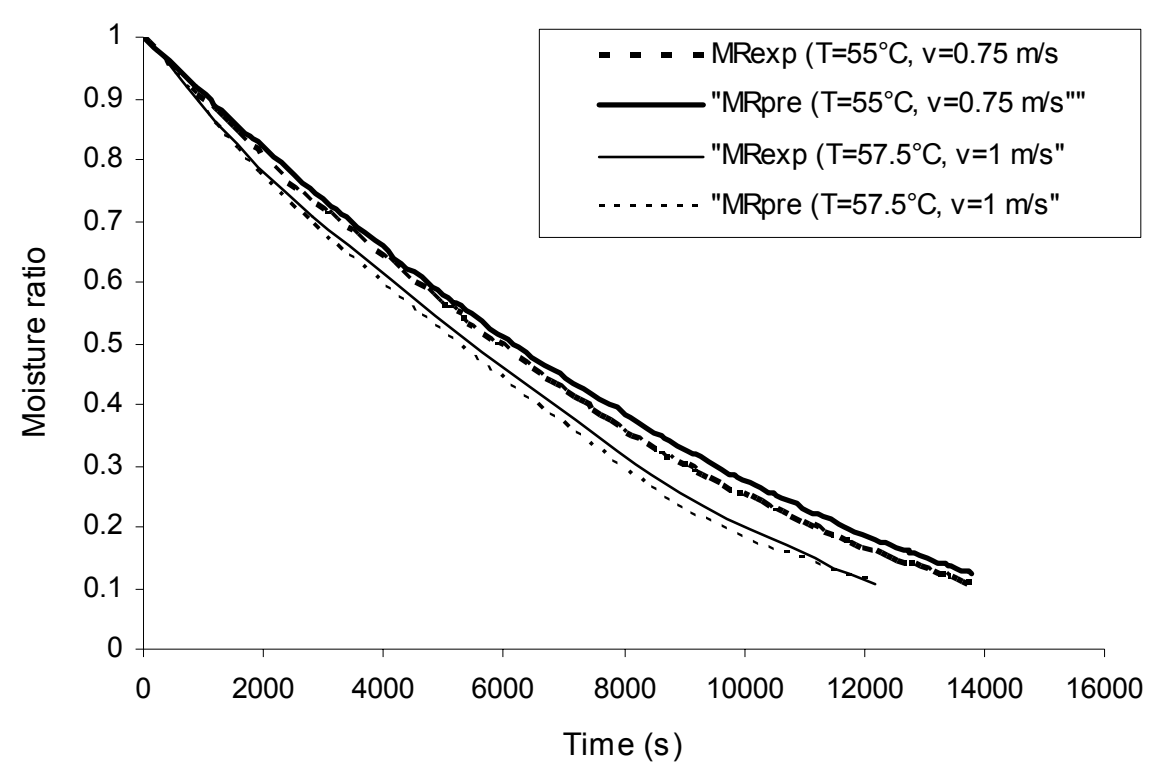

Figure 5. Comparison of predicted moisture ratio by developed model with experimental results. 


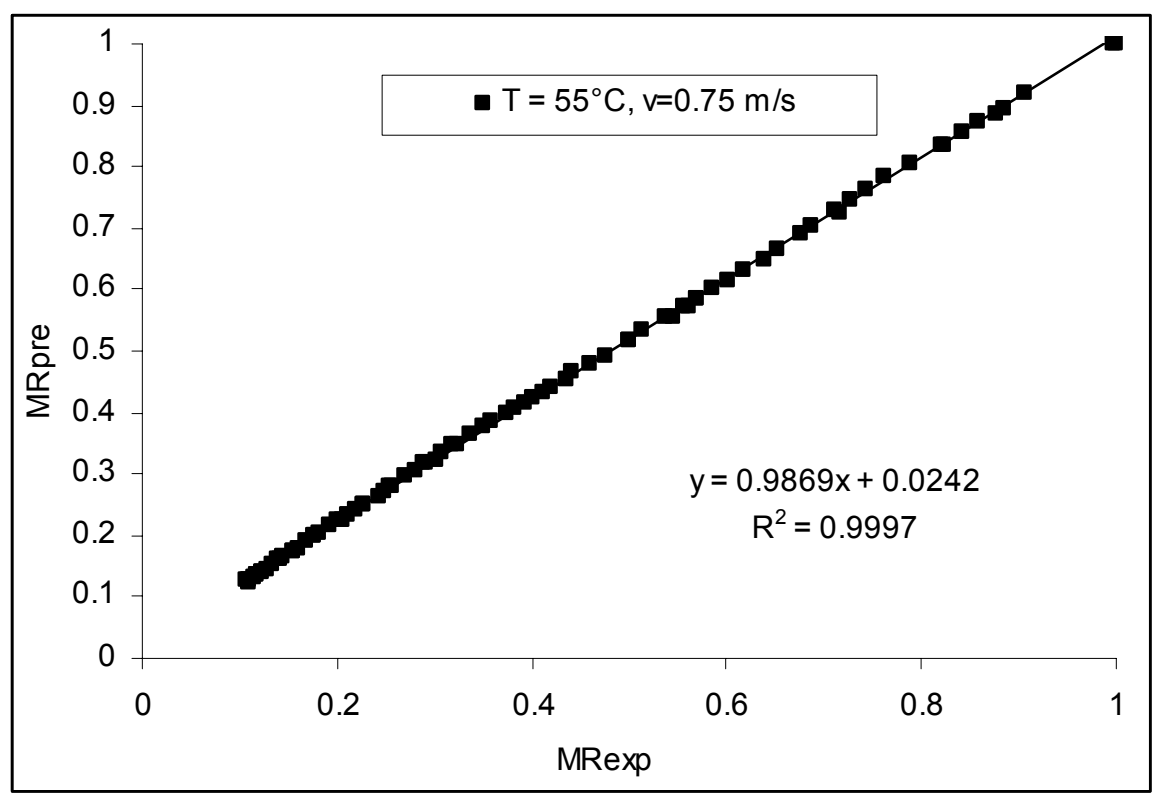

Figure 6. Regression line for comparing experimental and predicted moisture ratio by developed model.

where $a_{1}, a_{2}, b_{1}$ and $b_{2}$ were the linear functions of drying air velocity, and were obtained by regression analysis:

$$
\begin{gathered}
a_{1}=-4.64 \times 10^{-6} v+1.28 \times 10^{-6} \\
a_{2}=1.92 \times 10^{-4} v-1.19 \times 10^{-4} \\
b_{1}=3.73 \times 10^{-10} v-1.93 \times 10^{-10} \\
b_{2}=1.62 \times 10^{-8} v+9.73 \times 10^{-9}
\end{gathered}
$$

The reliability of the established models was evaluated by comparing the calculated moisture ratio at the different drying conditions with those obtained from the experiments. Figs. 5-6 show the moisture ratio predicted by the developed model in compared with the experimental data at $55^{\circ} \mathrm{C}$ and $0.75 \mathrm{~m} / \mathrm{s}$ and $57.5^{\circ} \mathrm{C}$ and $1 \mathrm{~m} / \mathrm{s}$. These figures show that the proposed model permits to obtain a satisfactory fit with experimental data of the $M R$ values during drying of the apple slices. It can be concluded that this model is appropriate to apply for prediction of water loss during drying and for better controlling the process and high quality production.

\section{Conclusions}

The effect of four drying temperature on convective drying of apple slices was studied. In order to explain the drying behavior of apple, ten selected different drying models from the literature were compared with their $r$ and $R M S E$ values.

According to the results, change of moisture ratio with time can be described by the Wang and Sing model in temperature range of $45-60^{\circ} \mathrm{C}$. This model is appropriate to apply for prediction of water loss during drying and for better controlling the process and high quality production.

\section{Nomenclature}
$a_{w}$
water activity
$a, b, c, g, h, k$ and $n \quad$ constants of drying models 


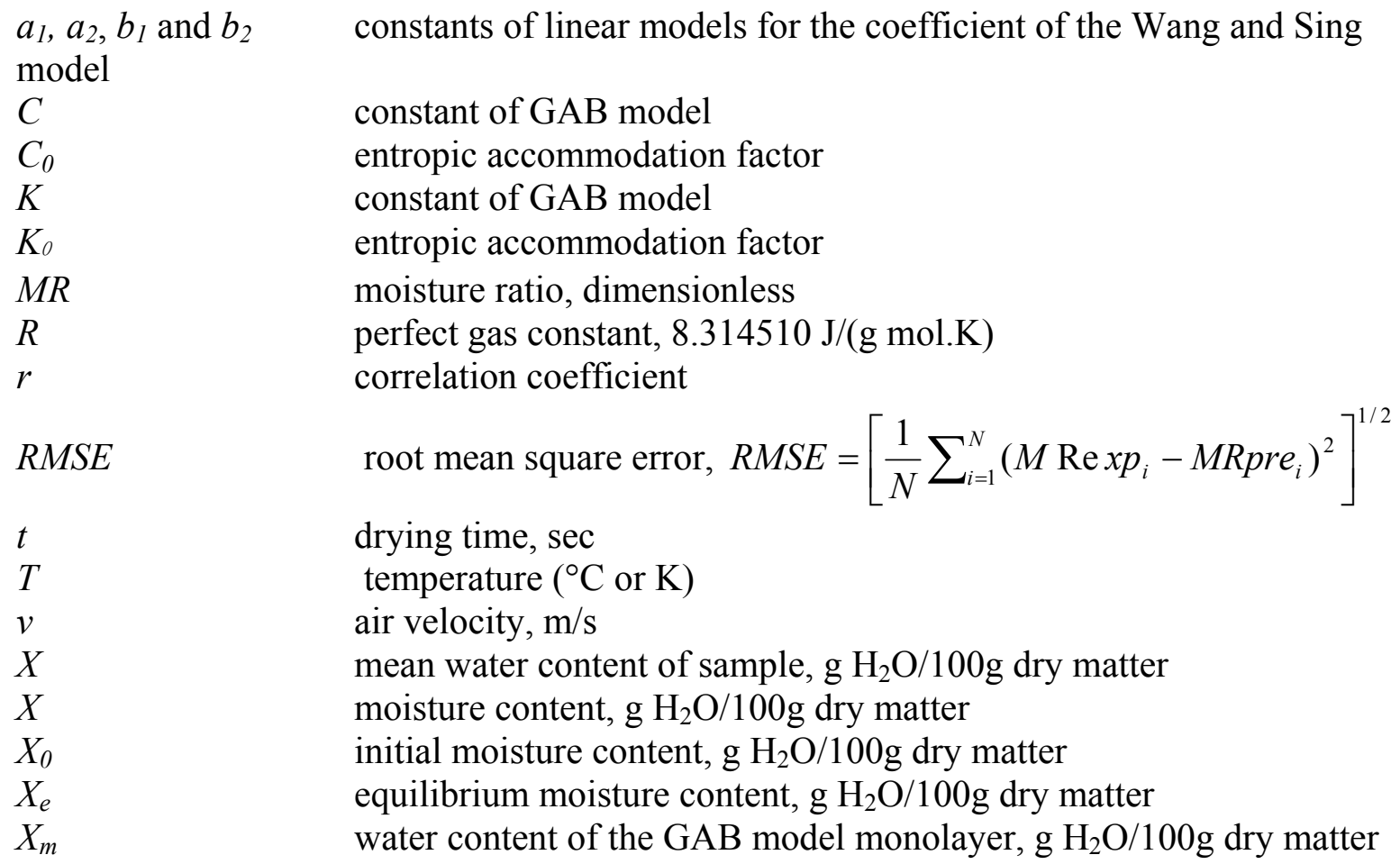




\section{References:}

Anders, A., C. Bilbao, et al. (2004). "Drying kinetics of apple cylinders under combined hot air-microwave dehydration." Journal of Food Engineering 63: 71-78.

Cao, W., Y. Nishiyama, et al. (2004). "Drying enhancement of rough rice by electric fieldU ". Biosystems Engineering 87(4): 445-451.

Demir, V., T. Gunhan, et al. (2004). "Mathematical modeling and the determination of some quality parameters of air-dried bay leaves." Biosystems Engineering 88(3): 325-335.

Demirtas, C., T. ayhan, et al. (1998" .(Drying behaviour of hazelnuts." Journal of Science of Food and Agriculture 76(559-564.(

Doymaz, I. (2004). "Convective air drying characteristic of thin layer carrots." Journal of Food Engineering 61: 359-364.

Doymaz, I. (2004b). "Pretreatment effect on sun drying of mulberry fruit (Morus albaL.)." Journal of Food Engineering 65(2): 205-209.

Doymaz, I. (2004c). "Convective air drying characteristic of thin layer carrots." Journal of Food Engineering 61: 359-364.

Ece, M. C. and A. Cihan (1993".(A liquid diffusion model for drying rough rice." Transacations of the American Society of Agricultural Engineers 36: 837-840.

Fortes, M. and M. R. Okos (1981). "Non-equlibrium thermodynamics approach to transport phenomena in capillary porous media." Transactions of the ASAE 24(3): 756-760.

Funebo, T. and T. Ohlsson (1998). "Microwave-assisted air dehydration of apple and mushoom." Journal of Food Engineering 38(3): 353-367.

Gaston, A. L., R. M. Abalone, et al. (2004). "Effect of modelling assumptions on the effective water diffusivity in wheat." Biosystems Engineering 88(2): 175-185.

Krokida, M. k. and D. Marinos-Kouris (2003). "Rehydration kinetics of dehydrated products." Journal of Food Engineering 57(1): 1-7.

Maroulis, Z. B., C. T. Kiranoudis, et al. (1995). "Heat and mass transfer modeling in air drying of foods." Journal of Food Engineering 26: 113-130.

Nieto, A., D. Salvatori, et al. (1998). "Air drying behaviour of apples as affected by blanching and glucose impregnation." Journal of Food Engineering 36(1): 36-79.

Simal, S., A. Femenia, et al. (2005). "Use of exponential , Page's and diffusional models to simulate the drying kinetics of kiwi fruit." Journal of Food Engineering 66: 323-328.

Velic, D., M. Planinic, et al. (2004" .(Influence of air flow velocity on kinetics of convection apple drying." Journal of Food Engineering 64: 97-102.

Velic, D., M. Planinic, et al. (2004c). "Influence of air flow velocity on kinetics of convection apple drying." Journal of Food Engineering 64: 97-102.

wang, J. and Y. Chao (2002). "Drying characteristics of irradiated apple slices." Journal of Food Engineering 52(1): 83-88. 